\title{
The Online Marketing Strategic Planning for Jember Coffee SMEs
}

\author{
Oktalia Juwita $^{1}$, Fajrin Nurman Arifin ${ }^{1}$, Fitriyana Dewi ${ }^{1}$ \\ ${ }^{1}$ Information System Department, University of Jember \\ Ioktalia.juwita@gmail.com, 22fajrin.pssi@unej.ac.id, ${ }^{3}$ fitriyana.d18@gmail.com
}

\begin{abstract}
Coffee is a kind of beverage that is widespread and much-loved in the world. Today coffee has become a lifestyle. Various kinds of coffee are offering in many shops. This is a great opportunity for entrepreneurs, especially SMEs providers of coffee products, in introducing and marketing variants of coffee products that are owned at the national and international level. One of the problems often arises in the marketing of SMEs products is the lack of information and marketing access to potential markets. An effective and appropriate marketing strategy is needed, especially for SMEs producing coffee products. The research method is done by observation and interview to get primary and secondary data. After the data obtained, analyzed the current condition using SWOT analysis and then followed by strategy mapping using SOSTAC method. From the analysis that has been done, needed a website for the directory to introduce SMEs engaged in the production and sale of coffee in Besuki Raya area.
\end{abstract}

Keywords: Coffee, SMEs, SWOT, SOSTAC

\section{Introduction}

Coffee is a kind of beverage that is widespread and much-loved in the world. Today coffee has become a lifestyle, for coffee lovers enjoying and trying a variety of coffee variants is a pleasure adventure. Nowaday, many shops are popping up and offer a wide range of coffee variants. This is a great opportunity for entrepreneurs, especially SMEs to introduce their product of coffee variants and improved marketing to both national and international levels. This opportunity is also getting bigger considering that Indonesia is the third largest country of coffee producer in the world after Brazil and Vietnam [1]. The existence of SMEs has a significant role in supporting national economic growth. As is well known, in the crisis that has been experienced by the nation when large companies have collapsed and laid off large numbers of employee, the SMEs with its flexibility are able to withstand that condition [2]. Apart from their flexibility in dealing with the economic crisis, there are several problems that often arise in SMEs, especially in the marketing sector like limited budgets, inadequate quality of resources, poor quality of production, limited information, and lack of information and marketing access to potential markets [3].

Considering two main things, coffee as a strategic commercial commodity and the importance of SMEs in supporting the nation's economy, special attention is needed in order to develop SMEs which producing coffee products. As we know, the rapid development of science and technology in the current era of globalization lead our business to Asean Economic Community. Competitors both goods and services are more and more exsist. This has led to competitive pressures where every business must be able to compete, produce and develop product marketing faster than before. On the other hand, there was also an information revolution where every business had very much information in running his business, so there are new problems which arose on how to use and manage the information appropriately [4]. One way that can be done to overcome these problems is by formulating strategic planning on marketing information systems for SMEs which producing coffee products. Marketing information systems play an important role to improve the efficiency of the businesses economic performance in highly competitive 
markets. The success of the marketing process depends on the marketing information system and each element in those system [5].

The use of an information system strategic plan in the development of information systems can generate the value of the development result. In the implementation stage, strategic planning can be used as the basis for the implementation of the information system which used by the organization. The addition of analytical methods in the stages of information system strategic planning provides added value in the form of effectiveness and efficiency in the use of the framework [6].

\section{Rudimentary}

There's a research that conducted by Marco (2015) which uses several stages of analysis to measure the condition of the organization's scope and utilization of information systems in the organization. The results of the study show the ability of organizational competitiveness against its competitors through the use of information systems. Other results obtained from the measurement of information system utilization are an appropriate strategic plan model and information system development suggestions for the progress of the organization [7]. The purpose of this study is to analyze the expected marketing performance. The result that has been achieved and analyze by the problems that arise in the marketing process that often arises in SMEs, can help to produce a strategic marketing information system plan that is suitable for SMEs. Marketing information systems are needed with the aim of identifying, measuring, estimate marketing opportunities, and also market segment analysis [5]. The marketing information system consists of people, facilities, and integrated procedures that are used to facilitate management with accurate and appropriate information about the environment related to marketing, which can help decision makers to read opportunities and develop marketing strategies and plans.

The research method used is observation and interview to obtain primary and secondary data. The obtained data is used in analyzing the current situation with SWOT method. SWOT analysis is used to identify various factors systematically to be used in formulating strategies [8]. SWOT analysis can identify strengths and opportunities to be maximized later, and identify weaknesses and threats so can be minimized [9]. After getting the results from the SWOT analysis, the result was carried out using the second analysis SOSTAC method. According to Michelle B. Cowley, SOSTAC is a continuation or extension from SWOT analysis [10]. SOSTAC is a framework model that can be easily used but is able to identify all the main things that must be done to achieve the goal. SOSTAC is an activity that describes the planning stages, among [11]:

1. Situation analysis: The first phase, discusses the current internal and external environmental conditions. An analysis of this has been done in the early stages of using SWOT analysis (to find out the strengths and weaknesses of the company's internal as well as opportunities and threats from external companies).

2. Objective: Measurement is more directed to whether the company's goals have been achieved and where it has arrived. The purpose of marketing communication is more about the level of awareness of the brand or customer brand. Usually brand testing, product preferences and positioning can be carried out to get the customer's picture.

3. Strategy: The third stage, discusses the strategies that will be prepared by the company to achieve the objectives that have been made, namely:

a) Segmentation, a company is able to identify and reach areas targeted by the market, so that the company can expand its target market.

b) Targeting, targeting approach is used to identify who the target customers want to reach a company.

c) Positioning, a company is required to determine how to accentuate benefits as a differential advantage over competing products.

4. Tactics: is a collection of details of this strategy usually contains about the process of development and creativity. At this stage an artistic value is needed from the 
preparation of marketing communication designs, such as innovative promotions, sales that delight customers or sensational exhibitions.

4. Action: this is needed in placing facilities into implementation. The company's internal activities support in relation to the delivery of communication and messages to the public when linked to time.

5. Control: to find out whether the strategy and tactics on the target are suitable between planning and operational. Monitoring and controlling the question of whether the strategy is running as desired

The study was conducted on several SMEs players providing coffee products in the Besuki Raya region. Five samples of SMEs were taken in Jember, Bondowoso, and Situbondo.

\section{Research Methodology}

In mountainous areas from Jember to Banyuwangi there are many Arabica and Robusta coffee plantations. Jember is already known to the world as region that produce a quality and delicious Javanese coffee.

Currently in Jember, Bondowoso, and Situbondo, there are many SMEs in the trade sector that process and sell coffee products. The quality of coffee offered by SMEs players is not inferior or even better than coffee products sold outside. They are quite capable and mastered about how to process coffee beans to produce a high flavor. It's just that the problem faced is the lack of knowledge of these SMEs actors about how to market the products they have to be known by the public and can increase income from the businesses they run.

Based on a survey of five SMEs engaged in processing and selling coffee products in the Jember area, Bondowoso, and Situbondo, there was a similarity in the vision of being the provider of Nusantara coffee products in the eastern region with the best taste and quality. While the steps they have taken so far, include:

a. Choose good quality coffee beans from farmers

b. Processing various types of Nusantara coffee

c. Produce various types of coffee products with a high flavor

d. Market coffee products through several social media, coffee shops and cafes in the area around Besuki Raya

To get a strategic marketing information system plan for Coffee SMEs, we took samples of 5 SMEs Coffee in Jember, Bondowoso, and Situbondo, and analyzed the SWOT method and mapped strategies using the SOSTAC method.

\section{Result and Discussion}

\subsection{Situation Analysis}

In the SOSTAC framework, the first stage is to find out the overall internal and external conditions of the Coffee SMEs. To find out these conditions, a SWOT analysis is used. The results of the SWOT analysis that have been carried out are as follows:

a) Strengths

1. has several coffee product variants

2. understand how to process good coffee

3. has sophisticated tools for processing coffee beans

4. has good flavor and quality coffee

5. understand about various types of coffee and the characteristics of each different type of coffee

6. has a local coffee community that is quite solid

7. Already have a social media account

b) Weakness

1. Limited number of workers

2. Limited amount of production

3. Lack of marketing network outside 
4. Promotion is done door-to-door and several social media accounts

5. Not yet optimal in utilizing social media accounts

c) Opportunities

1. Coffee is a primary need at this time, not only for local capacity but also internationally

2. Many cafes and restaurants business people need suppliers of various types of coffee products

3. Many people know and know about different types of coffee and want to try it

4. Local coffee products have become known by the public

5. There is the largest PUSLIT Coffee and Cocoa in Indonesia located in Jember

6. Many Arabica and Robusta coffee plantations along the Jember-Banyuwangi mountains

d) Threats

1. Many coffee entrepreneurs are already big and have a good reputation outside the Besuki Raya area

2. Coffee entrepreneurs with large capital, producing coffee with a mass amount so that they can sell at low prices

3. The majority of people only know about coffee products outside Java (Aceh Gayo, Flores, Bali Kintamani, Toraja)

\subsection{Objective}

In the framework of SOSTAC, the second stage is to discuss the purpose of marketing activities for Coffee SMEs. The goal of marketing Coffee SMEs is to introduce local coffee types in the Besuki Raya area through the production of coffee products from Coffee SMEs in the Besuki Raya area, both to the regions in the archipelago and internationally. By introducing Coffee products produced by Coffee SMEs in the Besuki Raya region, it is hoped that later it can help increase sales of the Coffee SMEs.

\subsection{Strategy}

Strategies that can be used by Coffee SMEs in Besuki Raya area to reach a wider market include the introduction and sale of products online. To do that, it is hoped that each Coffee SMEs has its own custom online media. In addition to supporting the Coffee SMEs in Besuki as a whole, a website directory containing a list of Coffee SMEs can be made in the Besuki Raya region, where the website can also connect directly to each website owned by each Coffee SMEs. Through the online media, Coffee SMEs can attract the attention and sympathy of the community (target market) with various issues and news that comes from something that has negative impressions to be positive.

\subsection{Tactics}

The fourth step of the SOSTAC framework is tactics. With relatively limited capital, things that can be done to improve marketing sparingly are creating a free website, for example by wordpress or buying portals and hosting at an affordable price (approximately around Rp. 350,000 - Rp. 1,000,000). In addition, Coffee SMEs players can also take advantage of social media such as Facebook pages, Twitter, Instagram, and others. This method is quite effective and also efficient in saving marketing costs.

\subsection{Action}

The next step is action. At this stage, what should be done by the Coffee SMEs players in the Besuki Raya area is to create a website with the hosting name of each of the Coffee SMEs. Besides that, it also creates accounts on several social media. Both on the website and social media that have been made, must pay attention to the content or content of the media. The thing that needs to be displayed in addition to the products marketed, is an explanation of each of these products. The explanations that need to be included are how 
the process of making coffee products is offered, how to present each of the coffee correctly, adding/sharing stories and knowledge about coffee in the archipelago.

Information about prices, availability of products offered, method of ordering and payment, must also be clear. Taking photos must be attractive so as to increase the interest of the expected target customer. After the website and social media account are ready, promotion is also necessary by placing paid online advertisements. The cost for advertising can be adjusted to the needs and abilities of each Coffee SMEs. On social media accounts, what needs to be considered is to create a target audience, where in this discussion, the target audience is men and women over 15 years. Another thing that must be done is to do a post that contains product knowledge or events that will or are ongoing related to the product offered. The duration needed to do the post is at least 4 times a day.

\subsection{Control}

Control that can be done is with two things, namely programs from online media that are owned and the number of performance and partners that are obtained every day and every month. For online media, things that need to be reviewed are an increase in the number of visits to online media owned. To be able to find out the increase in the amount of traffic from websites that are owned, can use Google Analytic. While the control effort that can be done for social media is by looking at the increase in the number of likes on Facebook Fans Page and the number of followers on Twitter or Instagram. In addition, you can also use the Tweet Reach Analytics program to find out the graphs of mentions activity on Twitter.

\section{Conclusion}

From the results of the research that has been done, conclusions can be drawn as follows:

a. Besuki Raya Region has great potential to produce quality coffee products.

b. Strategic planning of marketing information systems is needed to help SMEs in marketing coffee products they produce.

c. Marketing Information System Strategic Planning given in this study is using the SOSTAC method.

d. There are 6 stages of the SOSTAC method that need to be done, namely analysis of the situation, goals, strategies, tactics, actions and controls. The initial stage of the SOSTAC method is to find or study the problems that occur and can hamper the marketing process. The analysis carried out is to find out the internal and external conditions, one of them by conducting a SWOT analysis of the results of the SWOT analysis can be used to perform the next SOSTAC stages.

e. From the SOSTAC analysis described in the previous chapter, a website is needed for directories to introduce SMEs engaged in the production and sale of coffee in the Besuki Raya area.

From the SOSTAC analysis that has been described in the previous chapter, it is found that the things that are good suggestions for Coffee SMEs or other SMEs, among others:

1. Each Coffee SMEs also needs to have its own website to market their products.

2. In addition to the website, it is also necessary to have an account on several social media such as Facebook, Twitter and Instagram.

3. Need to actively conduct online marketing by advertising or posting on the timeline of each social media account

4. The things that need to be displayed in addition to the products that are marketed, are an explanation of each of these products. The explanations that need to be included are how the process of making coffee products is offered, how to present each of the coffee correctly, adding/sharing stories and knowledge about coffee in the archipelago. 
5. Control is needed with two things, namely programs from online media that are owned and the number of performance and partners obtained every day and every month.

\section{References}

[1] Kepala Pusat Komunikasi Publik, "Produksi Kopi Nusantara Ketiga Terbesar Di Dunia," 2013. [Online]. Available: http://www.kemenperin.go.id. [Accessed: 20Jun-2018].

[2] S. Wahyuningsih, "Peranan UKM Dalam Perekonomian Indonesia," Mediagro, vol. 5, no. 1, pp. 1-14, 2009.

[3] R. D. Hadiwidjaja and N. Hartati, "Tinjauan Umum Usaha Mikro Kecil dan Menengah Di Indonesia : Pe rmasalahan dan Strategi," 2013.

[4] M. Lindgren and H. Bandhold, "Scenario Planning - Revised and Updated Edition: The Link Between Future and Strategy," 2003.

[5] K. L. Kotler, Philip; Keller, Marketing Management, Edisi 12 B. Jakarta: PT. Salemba Empat, 2006.

[6] Arifin, F., N. (2013) "Perancangan Ulang Rencana Strategis Sistem Informasi Pemerintah Kabupaten Banyuwangi Menggunakan Metode TOGAF Framework dan IT Balanced Scorecard Sebagai Parameter Analisis Dari Organisasi”. Tesis Tidak Terpublikasi. Yogyakarta: Universitas Gadjah Mada.

[7] Marco, R. (2015) "Model Strategic Planning For Information System AMIK AMIKOM CIPTA DARMA Surakarta”. Jurnal Ilmiah DASI Vol.16 02 Juni 2015, halaman 48-55. ISSN: 1411-3201.

[8] U. Husein, Strategic Management in Action (Konsep, Teori dan Teknik Menganalisis Managemen Strategis, Strategic Business Unit Berdasarkan Konsep Michael R. Porter, Fred R. David, dan Wheelen-Hunger). Jakarta: Gramedia Pustaka Utama, 2003.

[9] F. Rangkuty, Analisis SWOT, Teknik Membedah Kasus Bisnis (Reorientasi Konsep Perencanaan Startegis untuk Menghadapi Abad 21). Jakarta: Gramedia Pustaka Utama, 2013.

[10] M. B. Cowley, “Jellies \& Jaffas': Applying PR Smith's SOSTAC Model to an Online," 2016. [Online]. Available: https://ssrn.com/abstract=2834279. [Accessed: 05-Jul-2018].

[11] D. Chaffey and P. Smith, E-Marketing Excellence Planning and Optimizing Your Digital Marketing, Fourth Edi. London, New York: Routledge, 2013.

\section{Authors}

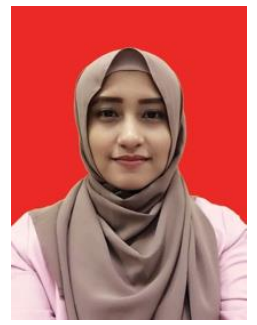

\section{Oktalia Juwita}

Information System Department, University of Jember

oktalia.juwita@gmail.com

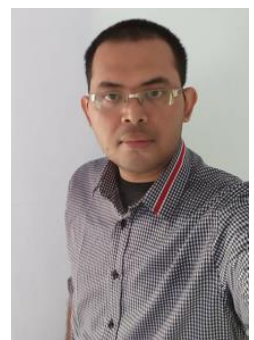

\section{Fajrin Nurman Arifin}

Information System Department, University of Jember fajrin.pssi@unej.ac.id 


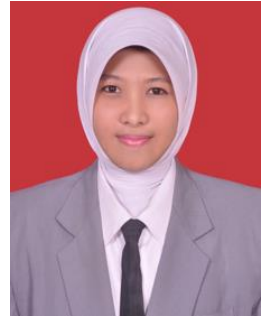

\section{Fitriyana Dewi}

Information System Department, University of Jember fitriyana.d18@gmail.com 